\title{
Radiotherapy and Radiosurgery for Cushing's Disease
}

\begin{abstract}
Patients with residual or recurrent Cushing's disease receive external beam radiotherapy (RT) with the aim of achieving long-term tumour control and normalization of elevated hormone levels. Treatment is given either as conventional radiotherapy using conformal techniques or as stereotactic radiotherapy, which is either used as fractionated treatment (SCRT) or as single fraction radiosurgery (SRS). We describe the technical aspects of treatment and report a systematic review of the published literature on the efficacy and toxicity of conventional RT, SCRT and SRS. There are no studies directly comparing the different radiation techniques and the reported results are inevitably of selected patients by investigators with interest in the treatment tested. Nevertheless the review of the published literature suggests better hormone and tumour control rates after fractionated irradiation compared to single fraction radiosurgery. Hypopituitarism represents the most commonly reported late complication of radiotherapy seen after all treatments. Although the incidence of other late effects is low, the risk of radiation injury to normal neural structures is higher with single fraction compared to fractionated treatment. Stereotactic techniques offer more localized irradiation compared with conventional radiotherapy, however longer follow-up is necessary to confirm the potential reduction of long-term radiation toxicity of fractionated SCRT compared to conventional RT. On the basis of the available literature, fractionated conventional and stereotactic radiotherapy offer effective treatment for Cushing's disease not controlled with surgery alone. The lower efficacy and higher toxicity of single fraction treatment suggest that SRS is not the appropriate therapy for the majority of patients with Cushing's disease. (Arq Bras Endocrinol Metab 2007;51/8:1373-1380)
\end{abstract}

Keywords: Fractionated stereotactic radiotherapy; Pituitary adenomas; Cushing's disease; Radiosurgery; Toxicity

\section{RESUMO}

\section{Radioterapia e Radiocirurgia para a Doença de Cushing.}

Pacientes com doença de Cushing residual ou recorrente recebem radioterapia externa em feixe (RT) com o objetivo de alcançar um controle tumoral prolongado e a normalização dos níveis hormonais elevados. O tratamento é realizado tanto com RT convencional, usando técnicas conformacionais, ou com RT estereotáxica, que é usada tanto como tratamento fracionado (RTF) ou como radiocirurgia em procedimento único (RCU). Descreveremos os aspectos técnicos do tratamento e mostraremos uma revisão sistemática da literatura sobre a eficácia e toxicidade da RT convencional, da RTF e da RCU. Não existem estudos comparando diretamente as diferentes técnicas de radiação, e os resultados reportados são inevitavelmente os de pacientes selecionados pelos investigadores com interesse no tratamento testado. De qualquer maneira, a revisão dos dados publicados sugere que há melhores taxas de controle hormonal e tumoral após RTF em comparação com RCU. O hipopituitarismo representa a complicação tardia mais comumente relatada da RT, vista após todos os tipos de tratamento. Embora a incidência de outros efeitos tardios seja baixa, o risco de a radiação comprometer estruturas neurais normais é mais elevado com RCU do que com RTF. Técnicas estereotáxicas oferecem irradiação mais localizada se comparadas com a RT convencional, embora um acompanhamento prolongado seja necessário para confirmar a possível redução da toxicidade continuada da radiação na RTF em comparação com a RT convencional. Com base na literatura disponível, a RT fracionada convencional e a estereotáxica oferecem tratamento efetivo para a doença de Cushing não controlada isoladamente pela cirurgia. A baixa eficácia e alta toxicidade do tratamento em dose única sugere que a RCU não seja a terapia mais apropriada para a maioria dos pacientes com doença de Cushing. (Arq Bras Endocrinol Metab 2007;51/8:1373-1380)

Descritores: Radioterapia fracionada estereotáxica; Adenomas hipofisários; Doença de Cushing; Radiocirurgia; Toxicidade

\section{atualização}

\author{
GIUSEPPE MINNITI \\ MichaEL BRADA
}

\author{
Department of Neurological \\ Sciences, Neuroendocrinology \\ Unit, NEUROMED Institute \\ (Pozzilli, IS), Italy (GM) and \\ Neuro-oncology Unit and \\ Academic Unit of radiotherapy \\ and Oncology, the Institute of \\ Cancer Research and the Royal \\ Marsden NHS Foundation Trust \\ (MB), Surrey, UK.
}

Recebido em 21/09/07

Aceito em 25/09/07 
$\mathbf{R}$ ADIOTHERAPY (RT) is used in patients with residual and recurrent pituitary adenomas; it achieves excellent long-term tumour control and normalization of hormone hypersecretion $(1,2)$. Although the perception is that radiotherapy is a potentially toxic treatment it is a well-tolerated non-invasive therapy with few serious complication. The only common late effect of irradiation is hypopituitarism with other toxicity occurring in less than $2 \%$ of patients.

In Cushing's disease radiotherapy is mostly employed as second line treatment after failure of surgery and medical treatment. Conventional fractionated external beam radiotherapy (RT) using a linear accelerator or a Cobalt unit has been the principal RT technique for over four decades. Modern techniques of external beam RT aim to reduce irradiation of normal brain through the development of conformal radiotherapy and more recently intensity modulated radiotherapy (IMRT), which is a variant of conformal radiotherapy. The precision of targeting radiation onto the tumour has further improved with the use of stereotactic techniques.

Stereotactic radiotherapy, which is essentially a precisely delivered conformal RT, can be given as a single treatment (described as stereotactic radiosurgery - SRS) or as fractionated stereotactic conformal radiotherapy (SCRT). Despite the theoretical advantages of stereotactic techniques, the potential benefit of normal tissue sparing remains to be demonstrated. More localised treatment relies on quality imaging and image interpretation with accurate delineation of the tumour, combined with rigorous and reliable quality assurance to ensure the desired accuracy is achieved in daily practice. Without these cornerstones such technologically intensive RT may even lead to worse outcome when compared to the less accurate wider field irradiation of conventional fractionated radiotherapy. The use of single fraction treatment may also lead to higher toxicity due to the higher risk of radiation injury associated with large single doses of radiation.

The only true assessment of the efficacy of modern treatment techniques is in the evaluation of treatment outcome using objective and comparable endpoints. We present a systematic review of the available literature on the efficacy and safety of conventional and stereotactic radiotherapy in patients with Cushing's disease.
TECHNICAL ASPECTS OF RADIOTHERAPY OF PITUITARY ADENOMA

\section{Conventional radiotherapy}

Modern external beam RT is given with photons generated by a linear accelerator. The steps in the treatment preparation include patient immobilisation, CT and MRI imaging for accurate localisation of the tumour and computerised 3 dimensional (3D) planning to achieve localised delivery of radiation conforming to the shape of the tumour. Patients are immobilised in a customised plastic mask with movement limited to $2-5 \mathrm{~mm}$. The pituitary adenoma is delineated on CT and MRI generally carried out specifically for the purpose of radiotherapy planning. $3 \mathrm{D}$ computerised planning defines the optimum number and orientation of beams to achieve a homogeneous dose to the adenoma and low dose to surrounding normal tissues particularly the brain. Conventional radiotherapy is generally delivered using three fixed radiation beams which conform to the shape of the tumour with the use of a multileaf collimator (MLC). This is described as conformal radiotherapy.

MLC leaves can be used to modulate the intensity of radiation and this is described as intensity-modulated radiotherapy (IMRT). Studies of dose distribution in tumour and normal tissue show no clear benefit for IMRT compared to fractionated stereotactic radiotherapy (SCRT) in the treatment of pituitary adenoma (3).

\section{Radiosurgery and stereotactic conformal radiotherapy}

Stereotactic irradiation can be given as single fraction radiosurgery (SRS) using either a multi-headed cobalt unit (Gamma Knife - GK) or a linear accelerator, or as stereotactic conformal radiotherapy (SCRT) delivered as fractionated treatment using a linear accelerator.

Patients undergoing SRS have traditionally been immobilized using invasive neurosurgical type frames. For fractionated SCRT patients are immobilized either in a relocatable frame or a precision mask system with relocation accuracy in the region of 1-2 mm. The tumour is delineated with MRI accurately co-registered with CT and the tumour position is defined using $3 \mathrm{D}$ coordinates with the aid of external fiducial markers as in stereotactic neurosurgery.

In SRS many small beams from multiple fixed cobalt sources of a multi-headed cobalt unit (Gamma 
Knife - GK) are collimated to produce small spherical high dose volumes ranging from 6 to $18 \mathrm{~mm}$ diameter. Larger and/or non-spherical tumours, such as the majority of pituitary adenomas, are treated by a combination of several spheres described as a multiple isocentre technique. Computerized 3D planning determines the number and distribution of isocentres often with selective occlusion of GK collimator apertures. SRS can also be carried out using multiple arcs of rotations of a linear accelerator employing a multiple isocentre technique. The dose distribution is equivalent to that achieved with GK treatment. This somewhat cumbersome technique has been largely superseded by multiple fixed field treatment.

SCRT beams from a linear accelerator are shaped with a mini or micro multileaf collimator (MLC) of $5 \mathrm{~mm}$ or $3 \mathrm{~mm}$ leaf width, which are automatically positioned to predefined shapes based on information transferred directly from the planning computer. The use of 4 to 6 rather than 3 beams improves the dose differential between the tumour and normal tissue and leads to further normal tissue sparing (4). For average shaped pituitary adenomas there is no clear therapeutic gain using a larger number of fixed beams (4).

High precision delivery can also be achieved with a small linear accelerator mounted on a robotic arm (Cyberknife) which is coupled with a room mounted X ray system which is able to check patient position and adjust the beam through treatment. The dose distribution and the precision of treatment are equivalent to frame based stereotactic techniques and the treatment is generally given with multiple small beams in 3 to 5 fractions.

SRS is given as a single dose of 18-24 Gy generally with the preparation and treatment carried out in one day. Fractionated conventional and stereotactic (SCRT) radiotherapy are given to a dose of 45-50 Gy in 25-30 daily treatments (fractions) at daily doses $\leq$ 1.8 Gy per fraction.

Large single doses of radiation as used in SRS are more toxic to normal brain structures than similar doses given in fractionated manner, as used in fractionated RT or SCRT. A well-defined dose-dependent risk of radiation optic neuropathy exists following single doses of irradiation and current practice of SRS therefore aims to avoid irradiating the optic apparatus to single doses beyond 8-10 Gy $(5,6)$. SRS can therefore only be offered to patients with small pituitary adenomas at least $5 \mathrm{~mm}$ away from the optic apparatus. By contrast, there is no restriction to the size of pituitary adenoma suitable for fractionated SCRT, since the delivered total doses are within tolerance of normal brain structures, including the optic apparatus. There is no clear difference in biological effectiveness between a single fraction treatment and a comparable fractionated course of RT measured as decline in elevated $\mathrm{ACTH}$ and cortisol and as long-term tumour control.

In summary, the precision achieved with stereotactic techniques allows for increased sparing of normal brain receiving high radiation doses. The additional precision of single treatment SRS compared to fractionated SCRT is not quantifiable in clinical terms and the potential benefit of either of the techniques requires robust clinical outcome data.

\section{EFFICACY AND TOXICITY OF IRRADIATION}

\section{Conventional radiotherapy}

Following conventional fractionated RT of ACTH secreting pituitary adenoma the reported tumour and hormone control at a median follow up of 8 years are $97 \%$ and $74 \%$ (table 1) (2,7-12). Urinary free cortisol (UFC) is reduced to $50 \%$ of pre-treatment value in 6-12 months $(10,12)$ and plasma cortisol in 12 months (12). Biochemical remission with normalisation of hormone secretion has been reported in 73\%, $78 \%$ and $84 \%$ patients at 3,5 and 10 years (12). The median time to reaching normal cortisol level was in the region of 24 months (12). Other reports of patients with Cushing's disease treated with postoperative RT record a remission rate of $83 \%$ with the majority reaching normal hormone levels within the first 2 years (10). Similar results have been reported in children with Cushing's disease (11).

Tumour control rate as 5- and 10-year actuarial progression free survival in 40 patients with Cushing's disease treated with postoperative RT was 93\%, and 5 and 10 year survival were $97 \%$ and $95 \%$ (12). This is similar to the control rate in patients with nonfunctioning pituitary adenomas $(1,2,13)$.

RT appears less effective when used as the sole treatment for Cushing's disease and when given to doses less than 40 Gy. This leads not only to lower remission rates but is also associated with a higher risk of biochemical recurrence (7-9).

Toxicity of RT as used in the treatment of pituitary adenoma is low. The most frequent late effect is hypopituitarism likely to be primarily due to hypothalamic injury. In patients with normal pituitary function 
Table 1. Results of conventional radiotherapy for Cushing's disease.

\begin{tabular}{|c|c|c|c|c|c|c|c|}
\hline \multirow[t]{2}{*}{ Authors } & \multirow{2}{*}{$\begin{array}{c}\text { patients } \\
\text { (n) }\end{array}$} & \multirow{2}{*}{$\begin{array}{l}\text { dose } \\
\text { (Gy) }\end{array}$} & \multirow{2}{*}{$\begin{array}{c}\text { follow-up } \\
\text { median (years) }\end{array}$} & \multirow{2}{*}{$\begin{array}{l}\text { control } \\
\text { rate } \\
(\%)\end{array}$} & \multirow{2}{*}{$\begin{array}{c}\text { hormone } \\
\text { normalization } \\
(\%)\end{array}$} & \multicolumn{2}{|c|}{ late toxicity (\%) } \\
\hline & & & & & & visual & hypopituitarism \\
\hline Howlett et al., 1989 (7) & $21^{*}$ & 45 & 9.5 & 100 & 57 & 0 & 30 \\
\hline Littley et al., 1990 (8) & 24 & 20 & 7.9 & NA & 46 & 0 & 10 \\
\hline Murayama et al., 1992 (9) & ) $20^{*}$ & 54 & 12.4 & 100 & 55 & 0 & 30 \\
\hline Tsang et al., 1996 (2) & 29 & 45 & 7.3 & 96 & 56 & 0 & 35 (at 10 years) \\
\hline Estrada et al., 1997 (10) & 30 & 50 & 3.5 & 100 & 83 & 0 & 35 \\
\hline Storr et al., 2003 (11) & 7 & 45 & 6.9 & 100 & 100 & 0 & 30 \\
\hline Minniti et al., 2007 (12) & 40 & 45 & 9 & 93 (at 10 years) & $\begin{array}{l}78 \text { (at } 5 \text { years) } \\
84 \text { (at } 10 \text { years) }\end{array}$ & 0 & 52 (at 10 years) \\
\hline Total & 171 & 44 & 8 & 97 & 68 & $\mathbf{0}$ & 34 \\
\hline
\end{tabular}

* RT as primary treatment of Cushing's disease without surgery; NA, not assessed

before irradiation, hormone replacement is required in $20-40 \%$ at 10 years. The reported incidence of radiation optic neuropathy resulting in visual deficit is $0-4 \%$ $(1,2)$ and the risk of necrosis of normal brain structures is rare $(0-2 \%)(14)$. The most feared late effect of RT for pituitary adenoma is the development of second radiation-induced brain tumour (15-17). The frequency is in the region of $2 \%$ at 20 years. Although there is an increased incidence of cerebrovascular accidents (CVA) in patients with pituitary adenoma treated with radiation (relative risk of 4 ), the contribution of radiation to the risk of CVA is not defined (18-20). While radiation is blamed for potential cognitive impairment, there is no clear evidence that irradiation of small volumes affects cognitive function beyond the deleterious effect of surgery, the tumour and endocrine abnormalities $(21,22)$.

\section{Fractionated stereotactic radiotherapy}

The data on the efficacy of fractionated SCRT in patients with Cushing's disease is limited. As the dosefractionation parameters are the same as used in conventional radiotherapy it is unlikely that the rate of decline of elevated hormone level and the tumour control rate will be any different. The 5-year tumour control in patients with all types of pituitary adenoma treated with SCRT is $98 \%(23-26)$. In a singe report of 12 patients with Cushing's disease hormone control was reported in 9 of 12 patients (24). While the technical advantages of stereotactic radiotherapy may translate into a meaningful clinical benefit in terms of reducing the potential long-term toxicity of irradiation, this has not yet been demonstrated and will require large cohort of patients and many years of follow-up.

\section{Radiosurgery}

The reported tumour control in SRS studies in patients with Cushing's disease was $94 \%$ at a corrected median follow-up of 45 months (table 2) (27-38). This compares to the 5 -year tumour control rate (progression free survival) in all pituitary adenomas of 91.5\% (39-42), which is worse than reported following fractionated RT even though the tumours treated are smaller. There is no information to assess the rate of decline of cortisol levels following SRS. Nevertheless the normalization of 24-h UFC or plasma cortisol concentration was reported in $48 \%$ of patients and the time to hormonal response ranged from 6 months to 3 years.

Seventeen of 40 patients with Cushing's disease treated by GK SRS (42.5\%) were in remission at a mean follow-up of $\mathbf{5 5}$ months, with a mean time to hormone normalization of 22 months (37). Jagannathan et al. (38) reported normalization in 49 of 90 patients $(54 \%)$ with Cushing's disease at a median follow-up of 45 months treated from 1990 and 2005 with a mean time from treatment to normalization of 13 months (range 2-67 months). Ten patients (20\%) had recurrence of disease after the initial remission, with a mean time to recurrence of 27 months. Similarly Devin et al. (36) reported hormone normalization in $42 \%$ of 35 patients treated with Linac SRS, with $20 \%$ of patients developing recurrent disease.

Following SRS hypopituitarism is reported in $24 \%$ of patients at an overall corrected median followup of 45 months. $10 \%$ of 90 patients ( 9 cases) with Cushing's disease developed cranial nerve deficits; 5 had ophthalmoplegia due to $3^{\text {rd }}$ or $6^{\text {th }}$ nerve palsies and 4 decrease in visual acuity presumed to represent optic radiation neuropathy (38). 
On the basis of the published evidence hormone and tumour control following SRS is inferior to that achieved with fractionated irradiation with a significantly higher risk of radiation toxicity. The claim for faster decline of elevated hormone concentrations and lower late toxicity following SRS remain unsubstantiated and based on more extensive experience in patients with acromegaly is unlikely (13).

\section{NELSON'S SYNDROME}

$30-50 \%$ of patients with Cushing's disease who undergo bilateral adrenalectomy develop Nelson's syndrome. Pituitary RT employed as a prophylactic measure to reduce the incidence of Nelson's syndrome results in pituitary tumour control of $91 \%$ at a corrected median follow-up of 7.8 years (table 3$)(7,46-50)$. In a retro- spective study of 56 patients with ACTH-dependent Cushing's syndrome treated by adrenalectomy, 5 out of 20 patients $(25 \%)$ who received prophylactic radiotherapy and 18 of 36 patients (50\%) without RT developed Nelson's syndrome at a median follow-up of 9.1 years (49). In a smaller cohort of 39 patients the incidence of Nelson's syndrome was $0 \%$ in irradiated and $50 \%$ in unirradiated patients at a median follow-up of 53 months (50). Similar results have been reported by others (46-48). The only reported complication of prophylactic irradiation is hypopituitarism, which occurs in $20-30 \%$ of patients at 5 years.

There is limited information on the efficacy of SRS in patients with Nelson's syndrome $(49,50)$. Mauermann et al. (50) treated 23 patients with GK SRS. At a median follow-up of 50 months the reported tumour control rate was $90 \%$. Hypopituitarism occurred in 4 patients and $3^{\text {rd }}$ cranial nerve palsy in one patient.

Table 2. Results of radiosurgery (SRS) for Cushing's disease.

\begin{tabular}{|c|c|c|c|c|c|c|}
\hline \multirow[t]{2}{*}{ Authors } & \multirow{2}{*}{$\begin{array}{c}\text { patients } \\
\text { (n) }\end{array}$} & \multirow{2}{*}{$\begin{array}{c}\text { follow-up } \\
\text { median (months) }\end{array}$} & \multirow{2}{*}{$\begin{array}{l}\text { control } \\
\text { rate } \\
(\%)\end{array}$} & \multirow{2}{*}{$\begin{array}{c}\text { hormone } \\
\text { normalization } \\
(\%)\end{array}$} & \multicolumn{2}{|c|}{ late toxicity (\%) } \\
\hline & & & & & visual & hypopituitarism \\
\hline Dagerbald 1986 (27) & 29 & 6 years & 76 & 48 & NA & 55 \\
\hline Kim et al., 1999 (28) & 8 & 26 & 100 & 60 & NA & NA \\
\hline Hayashi et al., 1999 (29) & 10 & $>6$ & 100 & 10 & 0 & 5 \\
\hline Inoue et al., 1999 (30) & 3 & $>24$ & 100 & 100 & 0 & 0 \\
\hline Izawa et al., 2000 (31) & 12 & $>6$ & 100 & 17 & NA & 0 \\
\hline Hoybye et al., 2001 (32) & 18 & 17 years & 100 & 83 & 0 & 66 \\
\hline Kobayashi et al., 2002 (33) & 20 & 60 & 100 & 35 & NA & NA \\
\hline Pollock et al., 2002 (34) & 9 & 36 & 85 & 35 & 35 & 8 \\
\hline Choi et al., 2003 (35) & 9 & 43 & 100 & 55 & 0 & 0 \\
\hline Devin et al., 2004 (36) & 35 & 35 & 91 & 49 & 0 & 40 \\
\hline Castinetti et al., 2007 (37) & 40 & 54 & 100 & 42 & 2,5 & 15 \\
\hline Jagannathan et al, 2007 (38) & 90 & 45 & 96 & 54 & 5 & 22 \\
\hline Total & 280 & 45 & 94 & 48 & 2 & 24 \\
\hline
\end{tabular}

NA, not assessed

Table 3. Results of conventional radiotherapy for Nelson's syndrome.

\begin{tabular}{|c|c|c|c|c|c|c|}
\hline \multirow[t]{2}{*}{ Authors } & \multirow{2}{*}{$\begin{array}{c}\text { patients } \\
\text { (n) }\end{array}$} & \multirow{2}{*}{$\begin{array}{l}\text { dose } \\
\text { (Gy) }\end{array}$} & \multirow{2}{*}{$\begin{array}{c}\text { follow-up } \\
\text { median (years) }\end{array}$} & \multirow{2}{*}{$\begin{array}{l}\text { control } \\
\text { rate } \\
(\%)\end{array}$} & \multicolumn{2}{|c|}{ late toxicity (\%) } \\
\hline & & & & & visual & hypopituitarism \\
\hline Orth et al., 1971 (44) & 20 & $45-50$ & NA & 100 & NA & NA \\
\hline Moore et al., 1976 (45) & 20 & $45-50$ & NA & 90 & 0 & NA \\
\hline Manolas et al., 1984 (46) & 12 & $45-50$ & 8 & 92 & 0 & NA \\
\hline Howlett et al., 1989 (7) & 15 & 45 & 9.6 & 93 & 0 & 20 at 5 years \\
\hline Jenkins et al., 1995 (47) & 20 & 45 & 9.1 & 75 & 0 & 15 \\
\hline Gil-Cardenas et al., 2007 (48) & 17 & 45 & 4.4 & 100 & 0 & 10 \\
\hline Total & 104 & 45 & 8 & 91 & $\mathbf{0}$ & 15 \\
\hline
\end{tabular}

NA, not assessed 
Conventional fractionated RT provides an effective prophylaxis for Nelson's syndrome with a pituitary tumour control rate of the order of $90 \%$ with a low incidence of late toxicity. The limited information and the short follow-up following stereotactic irradiation do not allow any conclusion about the comparative efficacy SRS.

\section{Recurrent pituitary adenoma}

A small proportion of patients with pituitary adenoma progress after radiotherapy. Treatment with further radiation has been considered risky because of presumed cumulative damaging effect of radiation of normal brain, particularly optic chiasm and nerves. Reported evidence from conventional fractionated treatment suggests that late recurrences (after 5 years or more) following conventional doses of $45 \mathrm{~Gy}$ in 25 fractions can be relatively safely reirradiated to more or less the same dose with acceptable efficacy and small risk of radiation optic neuropathy $(51,52)$.

Stereotactic techniques can further reduce the dose to the optic apparatus providing it is not in close proximity to the tumour. We have used SCRT in 10 patients with recurrent ACTH-secreting pituitary adenoma tumours after previous irradiation so far without late effects (unpublished) although longterm outcome data are not yet available. SRS has been employed in previously irradiated patients with recurrent Cushing's disease. The available data does not provide sufficient information on the efficacy of reirradiation with SRS or SCRT although retreatment with SRS is associated with considerable risk of cranial nerve deficit.

\section{CONCLUSION}

Radiotherapy remains an effective treatment in patients with Cushing's disease not cured by surgery. It achieves excellent long-term tumour control and normalisation of elevated hormone levels. Hypopituitarism represents the most commonly reported late complication of radiotherapy with low incidence of other late effects.

There is much debate about the relative efficacy of modern fractionated stereotactic radiotherapy (SCRT) and radiosurgery (SRS) in relation to conventional radiotherapy. There is currently no evidence of faster normalization of cortisol levels following single treatment compared to fractionated irradiation. The reported results suggest that SRS achieves worse hormone control than fractionated treatment with no evi- dence of faster rate of decline of elevated hormone levels compared to fractionated irradiation; yet it is associated with increased morbidity.

Treating less normal brain to higher radiation doses is a clear technical improvement of modern fractionated radiotherapy which may in the future translate into clinical benefit in terms of reduction of late effects of radiation. However, the relatively short follow-up does not provide sufficient information on the long-term efficacy and the potential reduction in the risk of late radiation induced toxicity.

New techniques of treatment require considerable infrastructure and quality control and wide ranging expertise in all clinical and technical aspects of pituitary adenoma management. The potential pitfall of relying on new technologies is demonstrated by the introduction of stereotactic irradiation (SRS) into the management of patients with pituitary adenoma. The widespread use of appealing new technology on the basis of belief alone has not only been of no clear benefit to patients with Cushing's disease but discarding tried and tested older treatment techniques may have resulted in worse outcome.

\section{ACKNOWLEDGEMENTS}

The work of the Neuro-oncology Unit was supported by the Neuro-oncology Research Fund of the Royal Marsden NHS Foundation Trust. The Neuro-oncology Unit also received funding from Cancer Research UK and the Royal Marsden NHS Foundation Trust. UK hospitals receive a proportion of their funding from the NHS Executive; the views expressed are those of the authors and not necessarily those of the NHS Executive.

\section{REFERENCES}

1. Brada M, Rajan B, Traish D, Ashley S, Holmes-Sellors PJ, Nussey $S$, et al. The long-term efficacy of conservative surgery and radiotherapy in the control of pituitary adenomas. Clin Endocrinol (Oxf) 1993;38:571-8.

2. Tsang RW, Brierly JD, Panzarella T, Gospodarowicz MK, Sutcliffe SB, Simpson WJ. Radiation therapy for pituitary adenoma: treatment outcome and prognostic factors. Int J Radiat Oncol Biol Phys 1994;30:557-65.

3. Khoo VS, Oldham M, Adams EJ, Bedford JL, Webb S, Brada $M$. Comparison of intensity-modulated tomotherapy with stereotactically guided conformal radiotherapy for brain tumours. Int J Radiat Oncol Biol Phys 1999;45:415-25.

4. Perks JR, Jalali R, Cosgrove VP, Adams EJ, Shepherd SF, Warrington $A P$, et al. Optimization of stereotactically guided conformal treatment planning of sellar and parasellar tumours based on normal brain dose volume histograms. Int J Radiat Oncol Biol Phys 1994;45:507-13. 
5. Tishler RB, Loeffler JS, Lunsford LD, Duma C, Alexander E $3 \mathrm{rd}$, Kooy HM, et al. Tolerance of cranial nerves of the cavernous sinus to radiosurgery. Int J Radiat Oncol Biol Phys 1993;27:215-21.

6. Leber KA, Bergloff J, Pendl G. Dose-response tolerance of the visual pathways and cranial nerves of the cavernous sinus to stereotactic radiosurgery. J Neurosurg 1998;88:43-50.

7. Howlett TA, Plowman PN, Wass JA, Rees LH, Jones AE, Besser GM. Megavoltage pituitary irradiation in the management of Cushing's disease and Nelson's syndrome: long-term follow-up. Clin Endocrinol (Oxf) 1989;31:309-23.

8. Littley MD, Shalet SM, Beardwell CG, Ahmed SR, Sutton ML. Long-term follow-up of low-dose external pituitary irradiation for Cushing's disease. Clin Endocrinol (Oxf) 1990; 33:445-55.

9. Murayama $M$, Yasuda $K$, Minamori $Y$ Mercado-Asis LB, Yamakita N, Miura K. Long-term follow-up of Cushing's disease treated with reserpine and pituitary irradiation. J Clin Endocrinol Metab 1992;75:935-42.

10. Estrada J, Boronat M, Mielgo M Magallón R, Millan I, Díez S, et al. The long-term outcome of pituitary irradiation after unsuccessful transsphenoidal surgery in Cushing's disease. N Engl J Med 1997;336:172-7.

11. Storr HL, Plowman PN, Carroll PV, François I, Krassas GE, Afshar $F$, et al. Clinical and endocrine responses to pituitary radiotherapy in pediatric Cushing's disease: an effective second-line treatment. J Clin Endocrinol Metab 2003;88:34-7.

12. Minniti G, Osti M, Jaffrain-Rea ML, Esposito V, Cantore G, Maurizi Enrici R. Long-term follow-up results of postoperative radiation therapy for Cushing's disease. J Neurooncol 2007:84:79-84

13. Brada M, Ajithkumary TV, Minniti G. Radiosurgery for pituitary adenomas. Clin Endocrinol (Oxf) 2004;61:531-43.

14. Becker $G$, Kocher $M$, Kortmann RD, Paulsen F, Jeremie B, Muller RP, et al. Radiation therapy in the multi modal treatment approach of pituitary adenoma. Stahlen Onkol 2002; 178:173-86.

15. Brada M, Ford D, Ashley S, Bliss JM, Crowley S, Mason M, et al. Risk of second brain tumour after conservative surgery and radiotherapy for pituitary adenoma. Br Med J 1992; 304:1343-6.

16. Tsang RW, Laperriere NJ, Simpson WJ, Brierley J, Panzarella T, Smyth HS. Glioma arising after radiation therapy for pituitary adenoma. A report of four patients and estimation of risk. Cancer 1993;72:2227-33.

17. Minniti G, Traish D, Ashley S, Gonsalves A, Brada M. Risk of second brain tumor after conservative surgery and radiotherapy for pituitary adenoma: update after an additional 10 years. J Clin Endocrinol Metab 2005;90:8000-4.

18. Brada M, Burchell L, Ashley S, Traish D. The incidence of cerebrovascular accidents in patients with pituitary adenoma. Int J Radiat Oncol Biol Phys 1999;45:693-8.

19. Brada M, Asley S, Ford D, Traish D, Burchell L, Rahan B. Cerebrovascular mortality in patients with pituitary adenoma. Clin Endocrinol (Oxf) 2002;57:713-7.

20. Erfurth EM, Bulow B, Svahn-Tapper G, Norrving B, Odh K, Mikoczy Z, et al. Risk factors for cerebrovascular deaths in patients operated and irradiatied for pituitary tumours. J Clin Endocrinol Metab 2002;87:4892-9.

21. Guinan EM, Lowy C, Stanhope N, Lewis PD, Kopelman MD. Cognitive effects of pituitary tumours and their treatments: two case studies and an investigation of 90 patients. J Neurol Neurosurg Psychiatry 1998;65:870-6.

22. Peace KA, Orme SM, Padayatty SJ, Godfrey HP, Belchetz PE. Cognitive dysfunction in patients with pituitary tumour who have been treated with transfrontal or transsphenoidal surgery or medication. Clin Endocrinol (Oxf) 1998; 49:391-6.

23. Milker-Zabel S, Debus J, Thilmann C, Schegel W, Wannenmacher M. Fractionated stereotactically guided radiotherapy and radiosurgery in the treatment of functional and non-functional adenomas of the pituitary gland. Int J Radiat Oncol Biol Phys. 2001;50:1279-86.
24. Colin P, Jovenin N, Delemer B, Caron J, Grulet H, Hecart AC, et al. Treatment of pituitary adenomas by fractionated stereotactic radiotherapy: a prospective study of 110 patients. Int $\mathbf{J}$ Radiat Oncol Biol Phys 2005;62:333-41.

25. Paek SH, Downes MB, Bednarz G, Keane WM, Werner-Wasik $M$, Curran WJ Jr, et al. Integration of surgery with fractionated stereotactic radiotherapy for treatment of nonfunctioning pituitary macroadenomas. Int J Radiat Oncol Biol Phys 2005;61:795-808.

26. Minniti G, Traish D, Ashley S, Gonsalves A, Brada M. Fractionated stereotactic conformal radiotherapy for secreting and nonsecreting pituitary adenomas. Clin Endocrinol (Oxf) 2006;64:542-8.

27. Degerblad M, Rahn T, Bergstrand G, Thoren M. Long-term results of stereotactic radiosurgery to the pituitary gland in Cushing's disease. Acta Endocrinol (Copenh) 1986; 112:310-4.

28. Kim SH, Huh R, Chang JW, Park YG, Chung SS. Gamma Knife radiosurgery for functioning pituitary adenomas. Stereotact Funct Neurosurg 1999;72(suppl):101-10.

29. Hayashi M, Izawa M, Hiyama H, Nakamura S, Atsuchi S, Sato $H$, et al. Gamma Knife radiosurgery for pituitary adenomas. Stereotact Funct Neurosurg 1999;72(suppl):111-8.

30. Inoue HK, Kohga H, Hirato M, Sasaki T, Ishihara J, Shibazaki $\mathrm{T}$, et al. Pituitary adenomas treated by microsurgery with or without Gamma Knife surgery: experience in 122 cases. Stereotact Funct Neurosurg 1999;72(suppl):125-31.

31. Izawa M, Hayashi M, Nakaya K, Satoh H, Ochiai T, Hori T, et al. Gamma knife radiosurgery for pituitary adenomas. J Neurosurg 2000;93(suppl):19-22.

32. Hoybye C, Grenback E, Rahn T, Degerblad M, Thoren M, Hulting AL. Adrenocorticotropic hormone-producing pituitary tumours: 12 to 22 -year follow-up after treatment with stereotactic radiosurgery. Neurosurgery 2001;49:284-91.

33. Kobayashi T, Kida Y, Mori Y. Gamma knife radiosurgery in the treatment of Cushing disease: long-term results. J Neurosurg 2002;97(suppl):422-8.

34. Pollock BE, Nippoldt TB, Stafford SL, Foote RL, Abboud CF. Results of stereotactic radiosurgery in patients with hormone-producing pituitary adenomas: factors associated with endocrine normalization. J Neurosurg 2002;97:525-30.

35. Choi JY, Chang JH, Chang JW, Ha Y, Park YG, Chung SS. Radiological and hormonal responses of functioning pituitary adenomas after gamma knife radiosurgery. Yonsei Med J 2003;44:602-7.

36.Devin JK, Allen GS, Cmelak AJ, Duggan DM, Blevins LS. The efficacy of linear accelerator radiosurgery in the management of patients with Cushing's disease. Stereotact Funct Neurosurg 2004;82:254-62.

37. Castinetti F, Nagai M, Dufour H, Kuhn JM, Morange I, Jaquet $P$, et al. Gamma knife radiosurgery is a successful adjunctive treatment in Cushing's disease. Eur J Endocrinol 2007; 156:91-8.

38. Jagannathan J, Sheehan JP, Pouratian N, Laws ER, Steiner L, Vance ML. Gamma Knife surgery for Cushing's disease. J Neurosurg 2007;106:980-7.

39. Petrovitch Z, Yu C Giannotta SL, Zee CS, Apuzzo ML. Gamma knife radiosurgery for pituitary adenoma: early results. Neurosurgery 2003;53:51-9.

40. Pollock BE, Carpenter PC. Stereotactic radiosurgery as an alternative to fractionated radiotherapy for patients with recurrent or residual nonfunctioning pituitary adenomas. Neurosurgery 2003;53:1086-91.

41. Losa M, Valle M, Mortini P, Franzin A, da Passano CF, Cenzato $M$, et al. Gamma knife surgery for treatment of residual nonfunctioning pituitary adenomas after surgical debulking. J Neurosurg 2004; 100:438-44.

42. Iwai Y, Yamanaka K, Yoshioka K. Radiosurgery for nonfunctioning pituitary adenomas. Neurosurgery 2005;56:699-705.

43. Assie G, Bahurel H, Coste J, Silvera S, Kujas M, Dugue MA, et al. Corticotroph tumor progression after adrenalectomy in Cushing's disease: A reappraisal of Nelson's Syndrome. J Clin Endocrinol Metab 2007;92:172-9. 
44. Orth DN, Liddle GW. Results of treatment in 108 patients with Cushing's syndrome. N Engl J Med 1971;285:243-7.

45. Moore TJ, Dluhy RG, Williams GH, Cain JP. Nelson's syndrome: frequency, prognosis, and effect of prior pituitary irradiation. Ann Intern Med 1976;85:731-4.

46. Manolas KJ, Farmer HM, Wilson HK, Kennedy AL, Joplin GF, Montgomery DA, et al. The pituitary before and after adrenalectomy for Cushing's syndrome. World J Surg 1984; 8:374-87.

47. Jenkins PJ, Trainer PJ, Plowman PN, Shand WS, Grossman $A B$, Wass JA, et al. The long-term outcome after adrenalectomy and prophylactic pituitary radiotherapy in adrenocorticotropin-dependent Cushing's syndrome. J Clin Endocrinol Metab 1995;80:165-71.

48. Gil-Cardenas A, Herrera MF, Diaz-Polanco A, Rios JM, Pantoja JP. Nelson's syndrome after bilateral adrenalectomy for Cushing's disease. Surgery 2007;141:147-51.

49. Pollock BE, Young WF Jr. Stereotactic radiosurgery for patients with ACTH-producing pituitary adenomas after prior adrenalectomy. Int J Radiat Oncol Biol Phys 2002; 54:839-41.
50. Mauermann WJ, Sheehan JP, Chernavvsky DR, Laws ER, Steiner L, Vance ML. Gamma Knife surgery for adrenocorticotropic hormone-producing pituitary adenomas after bilateral adrenalectomy. J Neurosurg 2007; 106:988-93.

51. Flickinger JC, Deutsch M, Lunsford LD. Repeat megavoltage irradiation of pituitary and suprasellar tumors. Int J Radiat Oncol Biol Phys 1989;17:171-5.

52. Schoenthaler R, Albright NW, Wara WM, Phillips TL, Wilson CB, Larson DA. Re-irradiation of pituitary adenoma. Int J Radiat Oncol Biol Phys 1992;24:307-14.

Address for correspondence:

Michael Brada

The Institute of Cancer Research and

The Royal Marsden NHS Foundation Trust

Downs Road, Sutton, Surrey, SM2 5PT

Fax: 44 (0) 2086613127

E-mail: michael.brada@icr.ac.uk 